\title{
The Proliferation of Cell Phones in High Schools: The Implications for the Teaching and Learning Process
}

\author{
Mncedisi C. Maphalala \\ University of South Africa, College of Education (Department of Curriculum \& Instructional Studies) \\ P.O. Box 392, Unisa, 0003, South Africa \\ mphalmc@unisa.ac.za
}

\author{
Mr M.V. Nzama \\ University of Zululand, Faculty of Education (Department of Arts, Languages and Social Sciences Education) \\ Private Bag X1001, Kwa-Dlangezwa, 3886, South Africa \\ nzamam@unizulu.ac.za
}

\section{Doi:10.5901/mjss.2014.v5n3p461}

\begin{abstract}
In recent years there has been a proliferation of cellphone use by learners in schools, and in classrooms in particular. If left unchecked the learners' use of cell phones in schools may impact negatively on the teaching and learning process. A mixedmethod research design was used to explore the extent to which learners use cellphones in high schools. This method explored how cellphones impact on the basic functionality of the schools. It also intended to find out if schools have policies guiding the use of cellphones in place. Questionnaires, semi-structured interviews and focus group interviews were used to collect data from 106 learners, 8 principals, 8 school governing body (SGB) members and 8 teachers from 8 schools drawn from two provinces in South Africa, namely Gauteng and KwaZulu-Natal. The study reveals that a considerable number of learners bring cellphones to schools on a regular basis. These cellphones sometimes disrupt the teaching and learning process. Not all schools have functional policies on the use of cellphones on their premises. Some schools have completely banned the use of cellphones within their premises due to security concerns and the distractions that result from their inappropriate use. Schools need to weigh all factors involved in the use of cellphones in order to make informed and appropriate decisions. Parents and the learners should decide on the pros and cons of taking cellphones to schools.
\end{abstract}

Keywords: social media; mobile phone; texting; technology

\section{Introduction}

In this world today the majority of high school going learners own cellphones. A growing number of learners from rural and urban areas go to school possessing a cellphone for various reasons. While a cellphone can be very useful (e.g. for learning purposes, emergency situations and keeping in contact with parents and friends), they can also have a negative impact on the teaching and learning process. Schools deal with the learners' use of cellphones within the school premises in various ways. Some schools completely ban cellphones while others allow them to be used only during lunch and break periods. Unfortunately, not much is written about the use of cellphones in schools in South Africa. Kreutzer (2009) observes that in the 1980s, cellphones were publicised as luxury technology items of the rich. They were also publicised as indispensable gadgets of the metropolitan and trendy who needed instant communication on the move. However, he points out that since network operators and phone manufacturers started targeting the large demand for affordable communication by the world's phoneless majority, cellphones have become a social phenomenon worldwide, especially in Africa. In recent years in South Africa teachers, parents, administrators and the public at large raised concerns about negative consequences associated with learners' proliferation of cellphone use in schools. This had sparked a debate for and against the learners' use of cellphones within school premises. Krevitt (2013) states that the New York City Department of Education under Mayor Bloomberg prohibited cellphones in schools, citing distraction and potential cheating as reasons for the ban. In South Africa the National Association of School Governing Bodies (NASGB) called for a ban on learners using cellphones in South African schools citing that cellphones are a "distraction that results in the disintegration of the teaching environment (Parent 24, 2013).

According to Corbeil and Valdes-Corbeil (2007), Clark Quinn who is professor, author and expert in computer- 
based education, defined mobile learning as the intersection of mobile computing (the application of small, portable and wireless computing and communication devices) and e-learning (learning facilitated and supported through the use of information and communications technology). He predicted that mobile learning would one day provide learning that was truly independent of time and place and facilitated by portable computers capable of providing rich interactivity, total connectivity and powerful processing. In May 2005, Ellen Wagner, senior director of Global Education Solutions at Macromedia, proclaimed that the mobile revolution had finally arrived. According to Parent 24 (2013) Ellen Wagner cites David Millar, principal of Norman Henshilwood High in Cape Town, who is one of the cellphone use advocates as saying:

\begin{abstract}
"Cellphones must not be seen as a curse. They must be seen as an opportunity for improved learning and exploration. Banning them defeats the purpose. Yes, they can be used for nefarious purposes. We need to 'legislate' that as much as we can. My school sees the cellphone as an amazing opportunity for use in the classroom to enhance teaching and learning."
\end{abstract}

Millar believes that people should see cellphones as mobile learning devices. Therefore, he created a policy for cellphone use in the school. Learners at the school are being encouraged in a controlled classroom environment to use their cellphones to research class topics on the web. Millar predicts that in years to come, all learners will be expected to have a notebook, cellphone or iPad, and that lessons at the school will become "more IT integrated and interactive".

The researchers caution that we should not condemn the learners' use of cellphones for educational purposes. She says while we promote ICT (information, communication and technology) for the classroom teaching in the 21st century, very strict cellphone policies have to be in place to avoid the unintended consequences.

This study examines the high school learners' use of cellphones within the school premises. Therefore, this paper sought to answer the following questions:

- What are the experiences of learners, teachers, principals and parents about using cellphones within the school premises?

- What do learners benefit from using cellphones?

- How does learners' cellphone use affect the teaching and learning process?

- Do schools have cellphone policies on the use of cellphones in place? If they have these policies, how do they implement them?

\title{
2. Research Methodology
}

This study adopts a mixed-method approach in the data collection process. Mixed-method research is the combination of quantitative and qualitative methods and analyses in a single study. Creswell in Maree (2007:261) defines it as "a procedure for collecting, analysing and mixing both types of data at some stage of the research process within a single study, to understand a research problem more completely". We administered a questionnaire to a randomly selected sample of 106 learners. We also conducted semi-structured interviews with 15 learners, eight principals, eight SGB members and eight teachers from eight schools drawn from two provinces in South Africa, namely Gauteng and KwaZulu-Natal.

Data analysis in mixed-methods research consists of analysing separately the quantitative data using quantitative methods and the qualitative data using qualitative methods. It also involves analysing both sets of information using techniques that mix the quantitative and qualitative data and results, namely the mixed-method analysis (Creswell \& Clark, 2011). In this study, both data analysis procedures were used to understand the collected data. The "interactive continuum" strategy (Newman \& Benz, 1998) was applied and data analysis occurred both within and between the quantitative (descriptive analysis) and the qualitative (description and thematic text).

Since the study adopted a mixed-method research approach, mean scores and ANOVA were computed to determine the statistical significance of differences between them. Themes were generated from the sections of the questionnaire and compared with the results obtained from the interviews with different respondents. Cross-tabulation was also used to investigate patterns or possible relationships in the data. According to Creswell and Clark (2011), when analysing data, researchers go through a similar set of steps for both quantitative and qualitative data analysis, namely preparation, exploration, analysis, representation, interpretation and validation.

\section{Findings}

Obringer and Coffey (2007) state that the expansion of cellphones during the past decade has made it commonplace for 
students and teachers to have them in the school setting. The first section of the questionnaire required learners to identify important features that they look for when choosing a cellphone. It also required learners to indicate whether or not they own cellphones and what they mainly do with them. Sixty-five per cent of the learners regard internet access as an important feature that they look for when given a chance to choose a cellphone. This allows them to download music, have access to social networks such as Facebook, MXit, Blackberry message, Whatsapp and Viber. Fifteen per cent of leaners just need a cellphone that does basic things such as making a call and sending an SMS. Seventeen per cent of learners when choosing a cellphone look for a cellphone with MMS, games, radio, pictures and video features.

Seventy-eight per cent of the learners who participated in the study own cellphones but only $57 \%$ of them carry their cellphones to schools. Learners also had to respond to the statements on the questionnaire as shown in table 1. In this study, we used chi-square with a .01 level of significance.

Table 1: Responses from the learners on the questionnaire statements

\begin{tabular}{|l|c|c|c|}
\hline & Yes & No & Sig \\
\cline { 2 - 4 } 1. I use my cellphone (s) to keep contact with my friends and family & $94 \%$ & $6 \%$ & $* *$ \\
\hline 2. I use my cellphone (s) to keep contact with my classmates and discuss work related to school & $47 \%$ & $53 \%$ & \\
\hline 3. I use my cellphone (s) to access school-related information from the internet & $59 \%$ & $41 \%$ & \\
\hline 4. The use of cellphones in the classroom is too disruptive to the learning process & $87 \%$ & $13 \%$ & $* *$ \\
\hline 5. I think cellphones could be used in high school as an educational learning tool & $76 \%$ & $24 \%$ & $* *$ \\
\hline 6. My school does not allow the use of cellphones for any purpose during school hours & $7 \%$ & $93 \%$ & \\
\hline 7. My school has a policy regarding the use of cellphones within the school premises & $55 \%$ & $45 \%$ & \\
\hline 8. In my opinion the learners' use of cellphones should be banned in schools & $71 \%$ & $29 \%$ & $* *$ \\
\hline 9. My parents allow me to carry a cellphone to school for safety reasons & $57 \%$ & $43 \%$ & \\
\hline 10. Some learners use cellphones to send pornographic materials to fellow learners & $11 \%$ & $89 \%$ & \\
\hline
\end{tabular}
${ }^{\star *} \mathrm{p}<.01$

- Statement 1: I use my cellphone (s) to keep contact with my friends and family. A significant number (94\%) indicated that they use their cellphones to communicate with their friends and family.

- Statement 2: I use my cellphones (s) to be in contact with my classmates and discuss work related to school. Only $47 \%$ of the participants use their cellphones (s) to keep contact with their classmates to discuss work related to school.

- Statement 3: I use my cellphones (s) to access school-related information from the internet. Only $59 \%$ of the learners use their cellphones (s) to access school-related information from the internet.

- Statement 4: The use of cellphones in the classroom is too disruptive to the learning process. A significant number $(84 \%)$ of learners agree that the use of cellphones in the classroom is too disruptive to the learning process.

- Statement 5: I think cellphones could be used in high school as an educational learning tool. Only $76 \%$ of learners think that cellphones could be used in high school as an educational learning tool.

- Statement 6: My school does not allow the use of cellphones for any purpose during school hours. Only 7\% of the learners indicated that their schools do not allow them to use cellphones for any purpose during school hours.

- Statement 7: My school has a policy regarding the use of cellphones within the school premises. Only $55 \%$ of the learners indicated that their schools have policies regarding the use of cellphones within the school premises.

- Statement 8: In my opinion the learners' use of cellphones should be banned in schools. The majority (71\%) of learners feel that the learners' use of cell phones should be banned in schools.

- Statement 9: My parents allow me to carry a cellphone to school for safety reasons. The parents of $57 \%$ of learners allow them to carry cellphones to school for safety reasons.

- Statement 10: Some learners use cellphones to send pornographic materials to fellow learners. Only $11 \%$ of the learners indicated that some learners use cellphones to send pornographic materials to fellow learners.

\subsection{Cellphone advantages}

Although learners acknowledge that cellphones can be a distraction during the teaching and learning process, they also 
point out numerous benefits that they enjoy by using their cellphones, which are mainly educational. Owning a cellphone allows learners to conduct school-related research on the internet, call for help in case of emergencies, calculate mathematical problems, take pictures for their school projects and record the lesson to replay at a later stage. In support of the use of cellphones, the learners said:

"I google concepts that I do not understand sometimes the dictionary is limited, certain words are not found on the dictionary, google also provides you with different ways in which the term can be used. In math, I sometimes use my phone as a calculator for simple mathematical problems, again the internet is very useful to in explaining math, for instance if you want to know how to calculate the area of a square the internet easily shows how to do it, step by step"

Sharples, Taylor and Vavoula (2007:223) concur that mobile phones theoretically make learner-centred learning possible by enabling students to customise the transfer of information and accessing it in order to build on their skills and knowledge as well as meeting their own educational goals. Another learner said the following:

"I'm all for cellphones at school because they could be used as a calculator and can also be used to extract information online. Moreover, you can call parents and friends in case something happens to you."

Learners claim that cellphones help to improve their English language proficiency. They get to know how to use the language properly and in the process they obtain more vocabulary. In support of this assertion, one learner said:

"It would help in class, like in a maths class. We could use the calculators that are on our phones. And for language class we can use a spell check or look up definitions of words and their usage. Our phones could help us a lot, we can read with, then we can do maths with them and instead of using paper."

On the other hand, teachers differ from the learners' views that cellphones serve as a catalyst for improving language proficiency. Teachers assert that cellphone communication does more harm than good in enhancing literacy among learners. Teachers claim that social networks jargon is now slowly creeping into learners' school work. Teachers have to deal with a lot of spelling errors in learners' writings evidently emanating from the social media influences.

Learners felt that cellphones are a necessity when there is an emergency. This is what one learner had to say:

"If you have an emergency then you could call somebody right away instead of asking to make a call from the teachers. By the time you rush to the teachers a life could have been saved. Some teachers think that phones are a distraction in the school environment, but it's not, we must know what is happening around us."

Another learner agreed and said:

"We should be allowed to use cellphones because you never know when an emergency will happen. Just imagine your phone rings and you don't respond to an emergency call just because you have to obey the school's rules and the next thing you regret it."

On the contrary, one SGB member said:

"Cellphones are bad news for our children, they just cannot let go of these gadgets. How then are they going to concentrate on their learning? They are not paying attention to the teacher during the lesson. We do not allow learners to use cellphones in our school. In case of emergency parents can contact their children through the school phone system".

\subsection{Cellphone disadvantages}

Despite the potential educational benefits of cellphones in a learning environment, the SGB members, teachers and learners agree that cellphones have a negative impact on the teaching and learning process. Seventy-one per cent of learners feel that the use of cellphones in the classroom is too disruptive to the learning process. Nworie and Haughton (2008) warn about unintended effects that accompany the adoption of technological innovation in the learning environment. They identify a host of disruptions accompanied by implementing mobile learning. These include technology-supported cheating, instant messaging, games, web surfing, lack of engagement with instructional setting caused by substitution of classroom experiences with pre-recorded and downloadable class materials from their cellphones. A learner participant agrees with this assertion and said: 
"They can be so distracting in the classroom especially when it rings. Learners use their cellphones in class and they don't even bother listening to the teacher. They pay more attention to their phones than to the teacher."

A teacher participant concurs by saying:

"Cellphones should not be allowed because they are a disturbance in the classroom. They should be allowed only when they go out on a school trip, so that in case of an emergency, they will be able to contact parents".

The teachers also raised concerns about allowing the use of cellphones especially during tests and examinations, fearing that this will promote cheating. Learners in one way or the other can manoeuvre to use their cellphones to find answers to the tests or examination questions. One school principal pointed out that cellphones contribute to cheating during tests and examinations:

"But cellphones should not be allowed during school hours, because they provide distractions for students and teachers. And we have previously caught learners cheating on tests and examinations claiming to be using cellphones to keep track of time. Allowing the use of cellphones in class obviously distracts the learner from active participation from the class and whatever the teacher is teaching and other learners are also distracted when a cellphone rings or a text message is received".

School governing body (SGB) member feels that the schools should not be left alone to deal with disciplinary problems emanating from learners' cellphone use within the school premises. This member said:

"Parents allow the children to carry cellphones to school which in turn they impact negatively on the learning and then teachers are left to deal with problems caused by these cellphones. Teachers should be allowed to teach without any unnecessary disturbances."

Other concerns from teachers, parents and learners about the learners' use of cellphones in schools include:

- Learners' addiction to social networks at the expense of their studies and other extra-curricular activities

- Learners stealing cellphones from one another

- High failure rate due to over preoccupation of learners on their cellphones (e.g. playing games and exploring other functions of interest to them)

- Stealing money to recharge airtime on their cellphones

- Exchange of pornographic materials among learners

- Reduced learners' mental capabilities due to over reliance on cellphones (e.g. learners do not bother to remember spelling of words and other facts because they can always access them at the click of the button)

\subsection{School policy on the learners' use of cellphones}

Schools in suburbs or towns mostly have written cellphone policies that both parents and learners have to sign and abide by. In rural and township schools cellphone policies are not written; they are in verbal format. Teachers largely remind learners about these policies during school assembly. One school provided a facility for the safekeeping of learners' cellphones. Cellphones are kept in the safes provided the learner hands it in at the beginning of the school day. If a learner does not hand in his/her cellphone, the onus is on learner to keep it safe and it must not be used within the school premises. If teachers find learners in possession of cellphones, the learners face disciplinary action.

The cellphone policy stipulations in various schools involve the following:

- The school discourages learners from bringing cellphones onto the school premises.

- Cell phones are confiscated should they ring or receive a message tone; sometimes a R100 fine has to be paid to redeem the phone; otherwise a learner gets it at the end of the year and learners are permitted to retain the SIM card of the phone.

In one previously advantaged school, cellphones have been embraced as an educational tool. Learners receive training on permissible uses of cell phones within the school premises and they have to adhere to the strict rules on when and how to use them.

Some schools have very strict cellphone policies, which state that if a teacher sees a learner with a cellphone, it must be confiscated and taken to the principal immediately. Then they inform the parent of the learner (transgressor) to come to fetch it. This is because teachers get disturbed while teaching with learners sending messages to one another 
during lessons and not focusing on learning. These learners also send pictures of a sexual nature to one another and using cellphones to cheat during exams and tests.

The cellphone policies whether written or unwritten do work to a certain extent, but from time to time learners contravene them because the consequences are not severe. The worst consequence is confiscating the cellphone until the end of the year, which learners regard as a slap on the wrist. These policies need to be strengthened and stern action need to be taken against the transgressing learners.

Generally, learners agree that cellphones should be banned because they disturb lessons and other formal school activities. They also agree that cellphones cause conflict among learners since they sometimes steal from one another and fight over them. One learner said cellphones should not be banned as they are useful for accessing information. Another learner argued that the cellphone policy should also apply to teachers; they should not be allowed to use cellphones at school because they also disturb teaching and learning. One of the learners disagreed with the rest and said teachers are human too. This learner pointed out that teachers have families and need to keep contact with them in cases of emergency. Therefore, teachers should be allowed to use cellphones anywhere and anytime at school.

\section{Conclusions}

This study concludes that the benefits of the learners' cellphone use outweigh the disadvantages if properly managed. Technology and cellphones are invaluable in our daily lives today, despite the fact that cellphones can be very disruptive to the teaching and learning process in schools. Most of the schools do not have enough resources such as computers to support the teaching and learning process. Therefore, cellphone use can mitigate for the shortage of resources in schools. Schools need to embrace cellphones as an educational tool but they should put watertight cellphone policies in place to ensure that technology benefits the education of the learners in the 21 st century and beyond.

\section{References}

Corbeil, JR \& Valdes-Corbeil, ME. 2007. Are you ready for mobile learning? Educause Quarterly, Vol. 2. Accessed at http://www.educause.edu/ero/article/are-you-ready-mobile-learning on 03 December 2013.

Creswell, JW. 2003. Research design: qualitative, quantitative and mixed methods approaches. 2nd edition. Thousand Oaks, Ca: Sage.

Creswell, JW. 2009a. Educational research: planning, conducting and evaluating quantitative and qualitative research. USA: Sage.

Creswell, JW. 2009b. Research design: qualitative, quantitative and mixed methods approaches.3rd edition. Thousand Oaks, Ca: Sage.

Kreutzer, T. 2009. Assessing cellphone usage in a South African township school. International Journal of Education and Development Using Information and Communication Technology (IJEDICT) 5(5):43-57.

Krevitt, D. 2013. Mobile storage trucks prove school cellphone bans really aren't doing much. Available at: http://www.huffingtonpost.com/david-krevitt/nyc-schools-cellphone-ban_b_3977307.html (accessed on 30 October 2013).

Maree, K. 2007. First steps in research. Pretoria: Van Schaik.

Nworie, J \& Haughton, N. 2008. Good intentions and unanticipated effects: the unintended consequences of the application of technology in teaching and learning environments. TechTrends 52(5):52-58.

Parent 24. 2013. Don't ban cell phones from schools. Available at:

http://www.parent24.com/Teen_13-18/development_behaviour/Dont-ban-cell-phones-from-schools-20120515 (accessed on 02 November 2013).

Sharples, M, Taylor, J \& Vavoula, G. 2007. A theory of learning for the mobile age, in The sage handbook of e-learning research, edited by R Andrews \& C Haythornthwaite. London: Sage Publications. 